\title{
Effect of Body Condition Score at Calving on Postpartum Performance of Murrah Buffaloes
}

\author{
Anitha Alapati, Sarjan Rao Kapa, Suresh Jeepalyam
}

10.18805/IJAR.B-4795

\begin{abstract}
Background: Body condition score (BCS) system is a subjective method to assess the body fat reserves particularly over the bony prominences like back and pelvic region. It is based on evaluation of the outer appearance of the animal that interacts with its body fat reserves and therefore is directly influenced by energy balance. Studies on the relationship between BCS and postpartum performance were meager in buffaloes. Hence, the present work was carried out to study the relationship between BCS at calving and postpartum performance in Murrah buffaloes.

Methods: The effect of body condition score at calving (BCSc) on the postpartum performance was studied in 24 Murrah buffaloes grouped based on BCS, maintained at Buffalo Research Station during 2018-19.

Result: The study showed that buffaloes of BCSc above 3.5 with significantly $(P<0.01)$ higher body weights showed better reproductive performance compared to buffaloes of BCSc groups below 3.5 with less body weights. The prepartum and weekly postpartum changes in BCS studied showed that the buffaloes gained a BCS of 0.57 from 3 months prepartum to one week prepartum, lost 0.17 BCS due to calving, further showed a decline in BCS up to 9 weeks of postpartum and then started regaining BCS gradually until 18 weeks postpartum. The mean LBCS over the period of 18 weeks postpartum was comparatively higher $(0.75 \pm 0.05)$ than $B C S$ restored in the early lactation which was shown as GBCS $(0.34 \pm 0.02)$. Buffaloes of BCSc group 3.5-3.99 showed the best reproduction performance among the four BCSc groups with less postpartum estrus period (46.66 days), service period (58.83 days), number of service per conception (1.50) and high rate of $1^{\text {st }}$ service conception $(66.66 \%)$
\end{abstract}

Key words: Body condition score, Loss in BCS post partum changes, Reproduction, Service period.

\section{INTRODUCTION}

Body condition score (BCS) has been recognized as a valuable tool in predicting the productive and reproductive performance of dairy cattle. The BCS of animal indirectly reflects the farm management or even more close to feeding management of the animal (Narendra Singh and Madhur, 2019). Body condition score (BCS) is strongly correlated with energy reserves, directly reflecting the fat reserves of individual dairy cows. The peripartum BCS and a series of changes, including the BCS at calving and the rate and degree of BCS reduction after calving, may indicate the increase of non-esterified fatty acids, possibility of postpartum diseases and differences in production performance (Pires et al. 2013, Rathbun et al. 2017). The postpartum delay in hyperphagia results in a mobilization of body tissue reserves to support milk production (Bauman and Currie, 1980). The dairy animals use their body reserves as an energy source in early lactation to support high milk yield that is why adequate amounts of nutrients must be stored in body tissues during late lactation. In early lactation the energy intake does not keep pace with continuously rising milk yield, as a result, energy deficit increases. This leads to a competitive situation between milk yield, fertility and health of the dairy cow because these traits are linked with energy requirement (Coenen, 2014). Both the duration and severity of this negative energy balance have been reported to influence reproduction (Beam and Butler, 1999). Body condition score at calving was reported to affect the
Department of Livestock Production Management, Sri Venkateswara Veterinary University, Tirupati-517 502, Andhra Pradesh, India.

Corresponding Author: Anitha Alapati, NTR College of Veterinary Science, Gannavaram-521 102, Andhra Pradesh, India.

Email: dranithaalapati@gmail.com

How to cite this article: Alapati, A., Kapa, S.R. and Jeepalyam, S. (2022). Effect of Body Condition Score at Calving on Postpartum Performance of Murrah Buffaloes. Indian Journal of Animal Research. DOI: 10.18805/IJAR.B-4795.

Submitted: 01-10-2021 Accepted: 21-12-2021 Online: 14-01-2022

interval from calving to first detected oestrus and first ovulation (Langley and Sherington, 1983, Rao and Anitha, 2013).

Although, relationship between BCS and postpartum performance in dairy cattle have received attention in the international literature, studies were meager in buffaloes. Hence, the present work was carried out to study the relationship between BCS at calving and postpartum performance in Murrah buffaloes.

\section{MATERIALS AND METHODS}

BCS system developed by Anitha et al. (2010) was used to score the buffaloes. The effect of BCS at calving (BCSc) on the post partum performance is studied in 24 Murrah buffaloes from Buffalo Research Station, Sri Venkateswara Veterinary University, West Godavari District of Andhra Pradesh during 2018-19. The buffaloes selected were in 
first to third lactation. Buffaloes were grouped based on BCSc in 4 groups, Group $1-2.5$ to 2.99 , Group 2 - 3.0 to 3.49 , Group 3 - 3.5 to 3.99 and Group $4-4.0$ to 4.49 with 6 buffaloes in each group, in a $4 \times 6$ completely randomized design to study the relationship between BCSc and performance. The body weights were taken two days after calving. Buffaloes were weighed before feeding and watering by using electronic platform balance.

The buffaloes were scored for body condition three months before calving and again at one week before calving. The buffaloes were scored at weekly intervals from calving (BCSc) to 18 weeks postpartum as LBCS / GBCS to study the postpartum changes in BCSc. BCSc was the first BCS assigned within three days after the buffaloes had calved. LBCS was calculated as the difference between BCSC and minimum BCS, whereas the minimum BCS refers to the lowest BCS obtained during the study lactation period of 18 weeks. GBCS was calculated as the difference between minimum BCS and BCS obtained at the end of the study lactation period of 18 weeks (Ruegg and Milton, 1995).

Postpartum estrus was observed by the acceptance of male by female which was the most prominent and reliable symptom of estrus in buffalo (Gordon, 1996). Vasectomized male was used for estrus detection in the farm. The service period was calculated from the date of calving to date of successful service (Thomas and Sastry, 1991). The data regarding number of services per conception were obtained from the data records of the farm. The first service conception rate was calculated by the percentage of experimental buffaloes conceived out of the total buffaloes at first insemination.

Analysis of Variance was used to study the relationship of BCSc with the body weights, weekly postpartum changes in BCS, LBCS, GBCS, minimum BCS, parity, parity and postpartum estrus, parity and service period. All the statistical procedures were as per the methods and formulae of Snedecor and Cochran (1994) as implemented in SPSS (Statistical Package for Social Sciences) statistical package version 21. The information obtained was analyzed and interpreted.

\section{RESULTS AND DISCUSSION Body weights}

Significant $(P<0.01)$ difference was observed in the body weight of buffaloes of various BCSc groups (Table 1). The relationship between body weights and BCSc was linear. Increase in body weight of $80.33 \mathrm{~kg}$ was observed for every one unit increase of BCSc between BCSc groups of 2.52.99 and $3.5-3.99$ and $82.34 \mathrm{~kg}$ between BCSc groups of 3.0-3.49 and 4.0-4.49. Delfino et al. (2018) also reported that high BCS group buffaloes with BCS of more than 3.5 at calving had higher $(p=0.01)$ average body weight than buffaloes with calving BCS of less than 3.5. The positive relation between BCS and body weight was also reported by Yildiz et al. (2011) and Tariq et al. (2013). Buffaloes of BCSc above 3.5 with significantly higher body weights
Table 1: Relationship between BCSc to the body weight of the test herd.

\begin{tabular}{lcc}
\hline BCSc & Body weight $(\mathrm{Kg})$ & 'F' value \\
\hline $2.5-2.99$ & $464.00^{\mathrm{c}}$ & \\
$3.0-3.49$ & $502.16^{\mathrm{bc}}$ & $6.52^{* *}$ \\
$3.5-3.99$ & $544.33^{\mathrm{ab}}$ & \\
$4.0-4.49$ & $584.50^{\mathrm{a}}$ & \\
\hline
\end{tabular}

$a, b, c:$ Values with different superscripts vary significantly $(p<0.01)$.

showed better reproductive performance compared to BCSc groups below 3.5 with less body weights which was in agreement with Gomez et al. (2018) and Paul et al. (2020).

\section{Prepartum and postpartum changes in BCS}

The mean $\pm S E$ value of BCS in the test herd was $3.10 \pm 0.10$ at 3 months before calving, $3.67 \pm 0.12$ at one week before calving, $3.50 \pm 0.12$ at calving and $3.62 \pm 0.12$ during the first week after calving. The BCS thereafter decreased to $2.91 \pm 0.13$ by 9 weeks postpartum and later on increased gradually to $3.15 \pm 0.13$ by 18 weeks postpartum. The loss in BCS (LBCS) during the first 9 weeks might have been attributed to loss in body fat reserves due to effect of calving and milk secretion and to a great extent by the peak milk yield. The recoupment in BCS in the remaining study period was mainly from the efforts of the buffaloes in replenishing their body fat reserves and lowered milk production as the lactation advanced. Based on the results at 18 weeks postpartum, it can be predicted that the buffaloes might have regained the normal BCS which they had at BCSc by the end of lactation. These findings were in accordance with the reported BCS losses by Wang et al. (2019). Mishra et al. (2016) also reported that body reserves decreased during early lactation until about 100 days in milk and were restored during mid and late lactation. Anitha et al. (2002) observed decrease in BCS to 10 weeks postpartum and thereafter gradual increase until 18 weeks postpartum in crossbred cows which were in tune with the present findings. Patel et al. (2018) also reported decrease in BCS after calving in Murrah buffaloes which continued up to $90^{\text {th }}$ day post partum.

Comparison of the prepartum and postpartum changes in BCS for various BCSc groups in the test herd showed that there was a significant $(P<0.01)$ difference in the mean BCS of buffaloes of various BCSc groups. The mean \pm SE values of BCS for BCSc groups of 2.5-2.99, 3.0-3.49, 3.53.99 and 4.0 to 4.99 were $2.41 \pm 0.02,3.01 \pm 0.03,3.34 \pm 0.03$ and $3.84 \pm 0.03$ respectively and the mean \pm SE values of BCS 3 months before calving were $2.45 \pm 0.05,2.87 \pm 0.06$, $3.34 \pm 0.04$ and $3.71 \pm 0.06$ respectively. Significant $(P<0.01)$ change was observed in the weekly postpartum BCS. Buffaloes of BCSc 3.5-3.99 started regaining their body condition 2 weeks in advance to the buffaloes of BCSc 2.52.99 and 3 weeks in advance to the buffaloes of BCSc groups 3.0-3.49 and 4.0-4.49.

The mean \pm SE values of LBCS and GBCS of the test herd were $0.75 \pm 0.05$ and $0.34 \pm 0.02$ respectively. The mean LBCS over the period of 18 weeks postpartum was comparatively higher $(0.75 \pm 0.05)$ than BCS restored in the 
early lactation which was shown as GBCS $(0.34 \pm 0.02)$. The difference of 0.41 units between LBCS and GBCS was observed over the period of 18 weeks postpartum. However, the buffaloes might have regained LBCS in the subsequent weeks of lactation, which was proved by the GBCS of 0.23 units within 9 weeks from $10^{\text {th }}$ week of postpartum which was in accordance with the findings of Anitha et al. (2002).

Significant $(P<0.01)$ difference was observed in the minimum BCS between BCSc groups but there was no significant difference in LBCS and GBCS (Table 2). Buffaloes of BCSc group 3.5 - 3.99 lost more BCS (0.80) and reached their minimum BCS 2-3 weeks earlier compared to other BCSc groups which might be due to their higher milk yields. This was in agreement with the general consensus that milk yield had an inverse relation with BCS during lactation. Anitha et al. (2020) reported that loss of body condition scores was higher for cows of higher dairy merit which was in tune with the present findings.

Postpartum estrus period, service period, number of services per conception, $1^{\text {st }}$ service conception rate

The relationship between BCSc, parity and postpartum estrus (Table 3 ) showed no significant difference in the postpartum estrus of buffaloes within BCSc and parity. The relationship between BCSc, parity and service period (Table 4) showed no significant difference in the service period of buffaloes within BCSc and parity. The results showed that there was significant difference in the reproductive performance among buffaloes of various BCSc groups whereas no significant difference was observed in the reproductive performance of buffaloes within BCSc and parity.

For every one unit increase in BCSc a decrease in postpartum estrus period of 20.5 days was observed. These findings were in tune with the reports of Langley and Sherington (1983) and Mishra et al. (2016) who observed that cows with higher BCS at calving had less interval to first detected oestrus.

For every one unit increase in BCSc a decrease in service period of 37.41 days was observed. These reports were in accordance to the reports of Lopez Gatius et al. (2003) that cows with a BCS of higher than 3.5 at parturition showed a significant reduction in the number of days open when compared with cows with a BCS of less than 3.5 at parturition. Yaylak (2003) also reported that as BCSc increased (<more or $=>3.50$ ), service period become shorter. The low BCS derived from the negative energy balance during the early lactation period resulted in extended postpartum estrus cycle and service period (Jilek et al. 2008 and Graff et al. 2017). Bayram et al. (2012) also reported that the service period of the cows with low condition score at calving was significantly longer.

For every one unit increase in BCSc a decrease in number in number of services per conception of 0.66 was observed. Yaylak (2003) and Anitha et al. (2011) also

Table 2: Relationship between BCSc to the LBCS, GBCS and minimum BCS of the test herd.

\begin{tabular}{lccccccccc}
\hline \multirow{2}{*}{ Groups of BCSc } & \multicolumn{3}{c}{ LBCS } & \multicolumn{3}{c}{ GBCS } & \multicolumn{3}{c}{ Minimum BCS } \\
\cline { 2 - 9 } & Mean & SE & 'F' Value & Mean & SE & 'F' Value & Mean & SE & 'F' Value \\
\hline $2.5-2.99$ & 0.78 & 0.09 & 0.35 & 0.40 & 0.04 & 0.75 & 1.98 & 0.11 & $21.08^{* *}$ \\
$3.0-3.49$ & 0.65 & 0.12 & & 0.30 & 0.05 & & 2.69 & 0.13 & 0.15 \\
$3.5-3.99$ & 0.80 & 0.13 & & 0.33 & 0.03 & & 2.97 & 0.13 & 0.12 \\
$4.0-4.49$ & 0.77 & 0.09 & & 0.30 & 0.05 & & 3.47 & \\
\hline
\end{tabular}

*Significant $(p<0.01)$.

Table 3: Postpartum estrus period for buffaloes of various BCSc groups and parity in the test herd.

\begin{tabular}{lccccc}
\hline BCSc & $2.50-2.99$ & $3.00-3.49$ & $3.50-3.99$ & $4.00-4.49$ & $\begin{array}{c}\text { Overall } \\
\text { Marity }\end{array}$ \\
\hline 1 & $86.50 \pm 4.95$ & $76.50 \pm 12.02$ & $59.00 \pm 9.89$ & $50.00 \pm 9.89$ & $67.75 \pm 6.51$ \\
2 & $72.00 \pm 5.65$ & $58.00 \pm 2.82$ & $53.50 \pm 9.19$ & $61.00 \pm 5.65$ & $61.12 \pm 3.28$ \\
3 & $73.00 \pm 19.79$ & $62.50 \pm 14.84$ & $37.50 \pm 0.70$ & $45.50 \pm 4.95$ & $54.62 \pm 6.68$ \\
Overall mean & $77.16 \pm 5.33^{* *}$ & $65.66 \pm 5.46^{* *}$ & $46.66 \pm 4.26^{* *}$ & $55.16 \pm 4.19^{* *}$ & 61.16 \\
\hline
\end{tabular}

**Significant $(p<0.01)$.

Table 4: Service period (days) for buffaloes of various BCSc groups and parity in the test herd.

\begin{tabular}{lccccc}
\hline \multicolumn{1}{c}{ BCSc } & $2.50-2.99$ & $3.00-3.49$ & $3.50-3.99$ & $4.00-4.49$ & $\begin{array}{c}\text { Overall } \\
\text { Parity }\end{array}$ \\
\hline 1 & $155.50 \pm 34.64$ & $76.50 \pm 12.02$ & $62.00 \pm 29.28$ & $91.00 \pm 55.15$ & $96.25 \pm 17.72$ \\
2 & $92.50 \pm 34.64$ & $90.00 \pm 21.21$ & $53.50 \pm 9.19$ & $73.50 \pm 23.33$ & $77.37 \pm 9.28$ \\
3 & $127.50 \pm 34.64$ & $90.50 \pm 2.12$ & $61.00 \pm 32.52$ & $67.00 \pm 35.35$ & $86.50 \pm 13.52$ \\
Overall $\quad$ Mean \pm SE & $125.16 \pm 17.42^{*}$ & $85.66 \pm 5.83^{*}$ & $58.83 \pm 9.01^{*}$ & $77.16 \pm 14.76^{*}$ & 86.70 \\
\hline
\end{tabular}

*Significant $(p<0.05)$. 
reported that number of services per conception was not significantly affected by BCS at calving in cows.

For every one unit increase in BCSc an increase of 33.33 per cent of $1^{\text {st }}$ service conception rate was observed. These findings were in agreement with the reports of Patel et al. (2018) who reported the positive effect of BCS at calving on the pregnancy to first service. Lopez Gatius et al. (2003) also observed that pregnancy rate at first Al showed a significant drop in cows delivering in poor condition. This reduced fertility could be a consequence of prolonged anovulatory intervals, which is frequent in thin cows and has a negative impact on first service conception rates.

\section{CONCLUSION}

Body condition score at calving has significant effect on the postpartum performance in Murrah buffaloes. The study suggested that buffaloes should have the target condition scores of minimum BCS of 3.25-3.5 at three months prepartum, should be able to attain a BCS of 3.5-3.99 at calving, should maintain a BCS of 2.75 to 3.0 at around 8 weeks postpartum and then should reach a BCS of 3.0 to 3.25 by 18 weeks postpartum in order to show good reproductive performance.

\section{REFERENCES}

Anitha, A., Sarjan Rao, K. and Suresh, J. (2020). Influence of body condition score on milk production parameters of Murrah buffaloes. Journal of Applied Life Science International. 23: $12-17$

Anitha, A., Sarjan Rao, K., Ramana, J.V., Satyanarayana, P.V.V. (2002). Effect of body condition score at calving (BCSc) on the postpartum changes in body fat reserves. Indian Journal of Animal Production Management. 18: 1-5.

Anitha, A., Sarjan Rao, K., Suresh, J., Srinivasa Moorthy, P.R. and Kotilinga Reddy, Y. (2010). Development of the body condition score system in Murrah buffaloes: Validation through ultrasonic assessment of body fat reserves. Journal of Veterinary Sciences. 11: 1-8.

Anitha, A., Sarjan Rao, K., Suresh, J., Srinivasa Moorthy, P.R. and Kotilinga Reddy, Y. (2011). A Body Condition Score (BCS) system in Murrah Buffaloes. Buffalo Bulletin. 30: 79-99.

Bauman, D.E., Currie, B. (1980). Partitioning of nutrients during pregnancy and lactation: A review of mechanisms involving homeostasis and homeorhesis. Journal of Dairy Science. 63: 1514-1529.

Bayram, B., Aksakal, V. and Akbulut, O. (2012). Effect of the Body Condition Score on some reproduction and milk yield traits of Swedish Red and White Cows. The Journal of Animal and Plant Sciences. 22: 545-551.

Beam, S.W., Butler, W.R. (1999). Effects of energy balance on follicular development and first ovulation in postpartum dairy cows. Journal of Reproduction and Fertility. 54: 411-424.

Coenen, H. and Peter, M.S. (2014). Associations among body condition score, body weight and milk weight in crossbred dairy cattle in a confined dairy operation. Tarleton State University. 42 pages.
Delfino, N.C., Bulcao, L.F.A., Alba, H.D.R., Oliveria, M.X.S., Queiroz, F.P.S., Carvalho, G.G.P., Renno, F.P., Junior, J.E.F. (2018). Influence of body condition at calving on the metabolic status and production performance of Murrah buffaloes during the transition period. Asian- Australasian Journal of Animal Sciences. 31: 1756-1765.

Gomeza, N.A., Conley, A.J., Robinson, P.H. (2018). Effects of longterm, near-term and real-timeenergy balance and blood progesterone concentrations, on the pregnancy rate of contemporary dairy cows. Animal Reproduction Science.189:136-145.

Gordon, I. (1996). Controlled Reproduction in Cattle and Buffaloes. Cab International Walling Ford, U.K. p. 450.

Graff, M., Süli, A., Szilágyi, S., Mikó, E. (2017) Relationship between body condition and some reproductive parameters of Holstein cattle. Advanced Research in Life Sciences.1: 59-63.

Jilek, F., Pytloun, P., Kubesova, M., Stipkova, M., Bouska, J., Volek J., Frelich, J. and Raymon, R. (2008). Relationships among body condition score, milk yield and reproduction in Czech Fleckvieh cows. Czech Journal of Animal Science. 53: 357-367.

Langley, D.H, Sherington, J. (1983). Effect of body condition scoring at calving on subsequent reproductive performance. Animal Production Research Report. Dunsinea Mcorepark and Western Research Centre, Dublin, p.59.

Lopez-Gatius, F., Yaniz, J., Madriles-Helm, D. (2003). Effect of body condition score and score change on the reproductive performance of dairy cows: a meta-analysis. Theriogenology 59: 801-812.

Mishra, S., Kumari, K., Dubey, A. (2016). Body condition scoring of dairy cattle: A review, research and reviews. Journal of Veterinary Science. 2. Available from: http://www.rroij.com/ open access/body-condition-scoring-of dairy- cattle-areview-.pdf

Narendra Singh and Madhur (2019). Body condition scores and its relationship with production and reproduction traits in buffalo- A review. Livestock Research International. 7: 243-249.

Patel, M., Lakhani, G.P., Ghosh, S., Nayak, S., Roy, B., Baghel, R.P.S., Jain, A. (2018). Effect of Body Condition Score on milk production, milk composition and reproductive performance of lactating Murrah buffaloes. International Journal of Current Microbiology and Applied Sciences. 7: 1204-1212.

Paul, A., Mondal, S., Kumar, S., and Kumari, T. (2020). Body condition scoring in dairy cows-a conceptual and systematic review. Indian Journal of Animal Research. 54: 929-935.

Pires, J.A.A., Delavaud, C., Faulconnier, Y., Pomiès, D., Chilliard, Y. (2013). Effects of body condition score at calving on indicators of fat and protein mobilization of periparturient Holstein-Friesian cows. Journal of Dairy Science. 96: 6423-6439.

Rao, K.S., Anitha, A. (2013). Body condition score (BCS) system in Murrah buffaloes. Buffalo Bulletin. 32: 1290-1298.

Rathbun, F.M., Pralle, R.S., Bertics, S.J., Armentano, L.E., Cho, K., Do, C., Weigel, K.A., White, H.M. (2017). Relationships between body condition score change, prior mid-lactation 
phenotypic residual feed intake and hyperketonemia onset in transition dairy cows. Journal of Dairy Science. 100: 3685-3696.

Ruegg, P.L., Milton, R.L. (1995). Body condition scores of Holstein cows in Prince Edward Island, Canada: relationships with yield, reproductive performance and disease. Journal of Dairy Science. 78: 552-564.

Snedecor, G.W., Cochran, W.G. (1994). Statistical Methods, Eighth Edition, lowa State University Press, Ames, lowa.

Tariq, M., Younas, M., Khan, A.B. and Schlecht, E. (2013). Body measurements and body condition scoring as basis for estimation of live weight in Nili-Ravi buffaloes. Pakistan Veterinary Journal. 33: 325-329.
Thomas, C.K., Sastry, N.S.R. (1991). Dairy Bovine Production. First Edition, Kalyani Publishers, New Delhi, p. 387.

Wang, Y., Huo, P., Sun, Y. and Zhang, Y. (2019). Effects of body condition score changes during peripartum on the post partum health and production performance of primiparous dairy cows. Animals. 9: 1159-1173.

Yaylak, E. (2003). Effects of body condition score on reproductive traits of Holstein cows. Hayvansat Uretim- Journal of Animal Production. 44: 44-51.

Yildiz, H., Saat, N. and Simsek, H. (2011). An investigation on body condition score, body weight, calf weight and hematological profile in crossbred dairy cows suffering from dystocia. Pakistan Veterinary Journal. 31: 125-128. 